\title{
Da sala de dona Benta para a sala de aula: contribuições para pensar a mediação da leitura literária na escola
}

Sônia Travassos*

* (Universidade Federal do Rio de Janeiro, Rio de Janeiro, RJ, Brasil)
Resumo: 0 trabalho discute como as mediações da leitura, perceptíveis na obra de Monteiro Lobato, podem se tornar pistas para pensar o trabalho com a literatura na escola. Foram analisadas estratégias de mediação em narrativas lobatianas, assim como a leitura mediada de uma delas, com crianças do $1^{\underline{0}}$ ano do ensino fundamental, em uma escola pública brasileira. Como metodologia, realizaramse leituras de obras de Lobato e de estudos sobre elas, observações participantes e entrevista com a professora da turma. Bakhtin (1988) e Benjamin (2002) embasam as concepções de linguagem e de sujeito e sustentam questões teórico-metodológicas desta pesquisa. No campo da leitura literária, buscou-se a interlocução com Amarilha (1997), Abramovich (1989), Bajard (2007), Lajolo (1994). Após as análises, destacou-se um conjunto de práticas de mediação que parecem contribuir para o encontro de crianças com a literatura.

Palavras-chave: Leitura literária. Escola. Mediações. Monteiro Lobato. 


\section{INTRODUÇÃO}

Este trabalho apresenta parte das discussões desenvolvidas numa pesquisa de mestrado, cujo objetivo geral foi o de analisar a obra infantil de Monteiro Lobato e suas relações com a infância e com a leitura, tanto no âmbito dela própria, como no diálogo com crianças do mundo atual. Entre as questões que nortearam a pesquisa, perguntamos: que concepções de infância e de leitura são perceptíveis na literatura lobatiana? É possível ler Lobato com as crianças na escola da atualidade? Que práticas de mediação de leitura podem favorecer esse encontro? Para respondê-las, foi realizada uma pesquisa qualitativa que, além da revisão bibliográfica, contou com dois movimentos: a leitura da obra infantil de Lobato, para analisar as concepções de infância e de leitura que a perpassam e a pesquisa empírica, para analisar a leitura desta obra na escola de hoje. Neste trabalho, nos deteremos nas análises referentes às práticas de mediação da leitura, observadas na obra de Lobato, e a mediação de sua obra Reinações de Narizinho (2007), com crianças do $1^{0}$ ำ ano do ensino fundamental, em uma das escolas públicas que foi campo da pesquisa.

A pesquisa situa-se no campo dos estudos da linguagem e tem como principais interlocutores Benjamin (2002) e Bakhtin (1988) - autores que concebem a linguagem na sua dimensão expressiva e como constituinte do sujeito e que contribuíram para as análises da pesquisa. Nos campo da literatura, da leitura literária e das mediações da leitura, dentro e fora do universo ficcional da obra, tivemos como interlocutores os estudos de Amarilha (1997), Abramovich (1989), Bajard (2007), Lajolo (1994), Zilberman (1987) e outros.

Para a análise sobre as mediações da leitura no universo da obra, o procedimento metodológico adotado foi a leitura da obra, em diálogo com os estudos de alguns dos pesquisadores citados acima sobre a interação das personagens com suas leituras. Com base nesse debate, foi problematizado como as passagens que envolvem a leitura e sua mediação no Sítio poderiam se tornar pistas para pensar a mediação da leitura literária e da leitura da própria obra de Lobato na escola. Nesse sentido, analisamos as estratégias de mediação exploradas pela personagem Dona Benta para aproximar seus ouvintes de textos literários, assim como o modo como estes reagem, em diferentes livros do autor.

Para o desenvolvimento da pesquisa no campo empírico, procurando analisar a interação dos alunos de uma turma de $1^{\underline{0}}$ ano do ensino fundamental 
(6/7 anos) com uma obra lobatiana, adotaram-se como procedimentos a observação participante em 12 aulas de literatura da turma e a entrevista com sua professora.

Considerando a perspectiva dialógica e polifônica desta pesquisa, pois revela nas análises realizadas não só a voz do pesquisador, mas a das crianças e a da professora da turma observada, assim como a dos autores que vêm estudando a leitura por dentro da obra de Lobato, este trabalho apresenta, em síntese, algumas práticas de mediação que podem contribuir para o encontro de crianças com a literatura e com a própria obra lobatiana, apontando ainda para alguns de seus modos de ler.

\section{LEITURA EM LOBATO}

Lobato possuía interesse em contribuir para a formação de leitores e desenvolveu em sua obra um verdadeiro projeto de difusão da leitura, reservando nas páginas que escreveu lugar especial para exemplificar o encontro das crianças com os livros. Assim, veremos ao longo da obra a personagem de Dona Benta aproximando as crianças de todo tipo de leitura, inclusive dos clássicos. Nesse sentido, desenvolve formas lúdicas e reflexivas de mediação: lê em voz alta e em capítulos, conversa com seus ouvintes, responde às suas questões, explica termos, quando necessário, resume partes do texto e lê outras por inteiro, brinca com as vozes das personagens. Em tais passagens, as crianças do Sítio torcem pelas personagens, trocam impressões, procuram respostas, ampliando suas experiências e visões do mundo.

Metaforicamente, poderíamos pensar em Dona Benta como uma professora que reúne crianças ao seu redor e, no embalo das palavras, abre espaços para o mergulho no imaginário e para a troca de experiências entre elas. Porém, a avó personagem não é uma professora. Seu contexto é o familiar, o que difere de uma sala de aula. Ao narrar histórias, no entanto, desenvolve estratégias de mediação que contribuem para a interação de seus ouvintes com os textos, o que pode ajudar a pensar as mediações dos adultos e as possíveis interações dos leitores em contextos reais.

\section{NA SALA DE DONA BENTA: DIALOGANDO COM HISTÓRIAS}

Para Bakhtin (1988), o sujeito é constituído socialmente, a partir da interação verbal na relação com o outro. No processo de construção da identidade do 
sujeito, os pensamentos e visões de mundo se elaboram a partir de relações dialógicas e valorativas com outros sujeitos, opiniões e dizeres. Nas cenas de leitura no Sítio, quando Dona Benta inicia uma leitura, os ouvintes fazem réplicas aos ditos do texto, marcando diferentes posicionamentos, trocando impressões, dando acolhida à palavra do outro, confirmando-a, rejeitando-a, ampliando-a. Assim, pensando com Bakhtin, analisamos duas passagens do livro Fábulas (2008), no qual Lobato reescreve as fábulas de Esopo e de La Fontaine, incluindo, ao término de cada uma delas, os comentários das personagens do Sítio e, dessa forma, sugerindo uma possível prática de mediação de leitura: ler e deixar que os ouvintes comentem ao final. Após a narração de Dona Benta, em “O burro na pele do leão”, Pedrinho e Emília entram em discordância:

- Bravos! - gritou Pedrinho. Está aí uma fábula que acho muito pitoresca. Gostei.

- Pois eu não gostei! - berrou Emília - porque trata com desprezo um animal tão inteligente e bom como o burro. Por que esse fabulista fala em "estúpida criatura?" E por que chama o pobre burro de “animalejo?” Animalejo é a avó dele...

- Emília! - repreendeu Dona Benta. - Mais respeito com a avó dos outros.

- É que eu não suporto essa mania de insultar um ente tão sensato e precioso como éo burro. Quando um homem quer xingar outro, diz: "Burro! Você é um burro!", e no entanto há burros que são verdadeiros Sócrates da filosofia, como o Conselheiro [...] (LOBATO, 2008, p. 48).

Emília não só discorda de Pedrinho, como explica os seus porquês, relacionando os conhecimentos que tem do mundo (o Conselheiro é o burro falante que vive no Sítio e é muito inteligente) com a situação que está criticando. Irreverente, não deixa de dar sua opinião, abrindo-se às réplicas dos demais ouvintes. Vejamos agora a conversa destacada de "O lobo velho":

- Bem feito! - berrou Emília. Uma burrinha dessas o melhor que podia fazer era entrar na boca do lobo. E, além disso, ovelha eu nem considero como bicho...

- Que é então? - perguntou Narizinho, admirada.

- É um novelo de lã por fora e costeletas por dentro. Ovelha é muito mais comida do que bicho. Não se defende, não arranha, não morde [...]. Bem feito! Eu gosto é das feras. [...] Urram, e é cada unhaço que arranca lanhos de carne do inimigo.

- Mas o ato da raposa você não pode aprovar porque foi traição - disse a menina.

- Isso é verdade. Para mim uma raposa dessas, só tiro na orelha. Vou fazer uma fábula em que em vez de sair ganhando, perde (LOBATO, 2008, p. 82). 
Analisando essa cena aos olhos de Bakhtin (1988) e compreendendo que nossas enunciações são respostas aos nossos interlocutores, observamos que Emília elabora uma resposta ao texto no sentido de compreendê-lo. 0 texto é um "outro" com quem a boneca dialoga, colocando suas palavras e revelando sua visão de mundo. Às suas palavras, Narizinho apresenta suas contrapalavras, provocando na boneca nova necessidade de resposta. Para Bakhtin, "compreender a enunciação de outrem significa orientar-se em relação a ela, encontrar seu lugar adequado no contexto correspondente" (1988, p. 132). É o que a boneca faz: em busca da compreensão, orienta-se em relação à enunciação da menina e encontra lugar para fazer nova réplica. Essa interação se repete por todo o livro e quando uma fábula entra em debate, a partir do momento em que as personagens do Sítio começam a emitir diferentes posicionamentos, identificando-se com suas personagens, comparando as situações narradas com as do mundo que conhecem, é que Lobato estaria dando "uma verdadeira aula de leitura, mostrando que os textos - inclusive as fábulas - não foram feitos para servir como lições a serem 'aprendidas', mas como objetos de reflexão, de debate, inclusive de recusa" (SOUZA, 2008, p. 114).

Adentro mais um livro de Lobato, Dom Quixote das crianças (2010), para observar estratégias de mediação de leitura usadas por Dona Benta para compartilhar com seus ouvintes narrativas mais densas, como a de Dom Quixote. Neste livro, para tornar a linguagem da história mais palatável aos netos (leitores iniciantes), Dona Benta a reconta usando suas próprias palavras. Para Lajolo (1994), porém, ao oralizar a narrativa do cavaleiro andante, a avó não deixa de conceber sua leitura como oportunidade de ampliar o universo cultural dos netos: “Meus filhos [...], esta obra está escrita em alto estilo, rico de todas as perfeições e sutilezas de forma, razão pela qual se tornou clássica” (LOBATO, 2010, p. 17). Apesar de estar contando o livro com suas palavras, lê partes de maior ação e alguns termos que estão no original para provocar a curiosidade das crianças. No intuito de envolvê-las na leitura, busca o tom coloquial, mas não deixa de ressaltar a importância da leitura integral do clássico: "quando vocês crescerem [...] havemos de ler a obra inteira nesta tradução dos dois viscondes, que é ótima” (LOBATO, 2010, p. 143).

Pode-se dizer que a mediação de Dona Benta é reflexiva, dialogada e acolhedora com os modos de ler das crianças, permitindo inclusive que fatos narrados da história sejam reinterpretados pelos ouvintes no calor da leitura, como acontece com Emília, que, identificada com o famoso cavaleiro, se 
transforma em “Dona Quixotinha”, para experimentar peripécias semelhantes às do clássico personagem no cotidiano do Sítio: nesse movimento provocado pela leitura, Emília se deixa alterar, alterando também os diferentes sujeitos participantes dele.

\section{A sala de Dona Benta e a sala de aula}

As sessões de narração de histórias do Sítio iniciam-se sempre por um ritual compartilhado entre adultos e crianças: "É hora gente! [...] Todos foram aparecendo e cada qual se sentou no lugar do costume" (LOBATO, 2007, p. 152). Sessão iniciada, a avó, durante sua leitura, utiliza diferentes estratégias de mediação: entre elas, dialoga com os leitores apontando semelhanças entre eles e os personagens, no intuito de fortalecer a verossimilhança e o envolvimento com o texto. Tal envolvimento, como analisa Lajolo (1994), contribui para que a identificação com as personagens se revele nas falas e ações dos ouvintes: identificado com um menino que havia levado uma sova na história de Dom Quixote e também com a própria bravura do cavaleiro, Pedrinho comenta: "Pois eu ia. Fugia e saía pelo mundo até encontrar de novo Dom Quixote e trazê-lo para rachar o brutamontes de alto a baixo com a lança” (LOBATO, 2010, p. 29).

A identificação das crianças do Sítio com as personagens das histórias que ouvem acontece em diferentes obras e de diferentes formas. Em Dom Quixote das crianças (2010), Emília veste, de corpo e alma, a máscara do personagem/ herói para experimentar seus dilemas e emoções, o que, como analisa Amarilha (1997), ocorre com as crianças (reais) ao envolverem-se numa narrativa. A identificação com as personagens de uma trama é um elemento que contribui para o mergulho do ouvinte na leitura: esse movimento de se colocar no lugar do outro permite a descoberta de novos sentimentos e de modos de compreender o mundo, favorecendo a elaboração de sentidos para o texto. Assim, é importante pensar como se dá essa identificação no ato da leitura. No caso da boneca, ela se dá de corpo inteiro, o que se aproxima do modo como crianças pequenas leem: não só com os olhos e ouvidos, mas mimetizando com o corpo gestos e ações das personagens com quem entram em empatia.

Outra das estratégias de mediação da leitura usada por Dona Benta é a interrupção dos capítulos em momentos emocionantes: “E depois? - indagou Pedrinho. - Depois, cama. Já são nove horas. Para a cama todos! Amanhã veremos o que aconteceu" (LOBATO, 2009, p. 65). Pensando na leitura em 
capítulos, na escola, Pimentel (2010) comenta que "ler em capítulos é uma prática que aguça a curiosidade a respeito do desenrolar de uma história mais extensa. Numa sala de aula, os ouvintes, diante dessa situação, poderão pensar coisas diferentes e, ao compartilhar suas ideias, rever e ampliar suas interpretações sobre a narrativa em andamento" (PIMENTEL, 2010, p. 11).

Porém, Dona Benta não interrompe a narração apenas devido à extensão do texto, mas para dialogar e responder às indagações das crianças. Zilberman (1987), ao discutir as interrupções da personagem na narração de Peter Pan, no livro Peter Pan (LOBATO, 2009), ressalta que sua atuação “indicia a presença de uma concepção sobre o papel do narrador. Se comenta e explica a ação, isso decorre sempre da solicitação das crianças, evitando introduzir seus valores no processo de narração" (ZILBERMAN, 1987, p. 100). A questão apontada faz refletir sobre o que ocorre em situações de narração de histórias nas escolas quando, não acreditando no fato de a criança ser capaz de compreender o que ouve, o mediador se antecipa, interpretando para ela os sentidos do texto.

Outra importante estratégia de Dona Benta diz respeito à própria habilidade de ler e contar histórias:

A moda de Dona Benta ler era boa. Lia "diferente" dos livros. Como quase todos os livros para crianças que há no Brasil são [...], cheios de termos do tempo do onça [...], a boa velha lia traduzindo aquele português de defunto em língua de Brasil de hoje. Onde estava "lume", lia "fogo" [...]. E sempre que dava com um boto-o, lia botou ele e ficava o dobro interessante. [...] E como naquele dia os personagens eram da Itália, começou a arremedar a voz de um italiano que às vezes aparecia no sítio [...]" (LOBATO, 2007, p. 36).

Nessa passagem de Reinações de Narizinho (2007), sugere-se que a narração de Dona Benta está apoiada no tex to escrito do livro. Ela atualiza alguns termos, mas não está adaptando a história: só quando esbarra em termos antigos é que os substitui. Diferente do que faz em Dom Quixote das crianças (LOBATO, 2010), quando começa lendo o texto do livro, mas, mediante a incompreensão dos leitores, passa a contar a aventura resumidamente, concentrando-se nos diálogos e nos momentos de ação. Essa estratégia por vezes utilizada por Dona Benta se relaciona com a visão de Abramovich (1989) sobre a leitura de histórias longas junto a crianças mais novas: "é bom evitar as descrições imensas [...] Ela quer ouvir mais as conversas, as ações, os acontecimentos" (ABRAMOVICH, 1989, p. 21). Essa autora também ressalta a importância de uma leitura que valorize o ritmo da narrativa e as modalidades da voz, como Dona Benta faz na tentativa de caracterizar os personagens de Pinóquio. 
Trazemos a diferenciação entre as formas de ler e de narrar oralizando de Dona Benta, pois elas remetem a reflexões sobre o trabalho com a leitura literária nas escolas e sua forte inter-relação entre oralidade e escrita, quando a leitura é realizada para crianças mais novas. De acordo com Bajard (2007), o adulto, muitas vezes, em lugar de ler o texto oralmente, realizando sua transmissão sonora, prefere traduzi-lo usando suas palavras. Para discutir essa questão, o autor remete também ao livro Dom Quixote das crianças (LOBATO, 2010), observando que Dona Benta começa a narrativa por uma transmissão vocal do texto original, mas ao perceber sua inadequação à compreensão das crianças, abandona-a para elaborar uma narrativa oral com sua própria língua; porém, para ele, “a tradução portuguesa antiga do Quixote justifica a mudança de estratagema de Dona Benta” (BAJARD, 2007, p. 80), diferente do que percebemos na prática de muitos educadores que contam histórias apoiando-se nas ilustrações dos livros, mas criam um texto próprio, ou os traduzem sem necessidade. Segundo o autor, a substituição sistemática do texto sonoro por um discurso improvisado acarreta consequências: pode adulterar a qualidade literária do livro, composto pela interação entre texto e ilustração, "embaralhar os limites entre língua oral e língua escrita, já que o ouvinte não identifica se a língua é oriunda do autor ou do mediador" (BAJARD, 2007, p. 81), além de não se valer da presença do livro para aproximar a criança da cultura da língua escrita. Pois, como ressalta Amarilha (1997), quando lemos para a criança, estamos proporcionando a ela estruturas acima do seu nível de leitura, "estamos tornando-lhe acessível o complexo mundo da escrita” (AMARILHA, 1997, p. 56).

As questões relacionadas à mediação da leitura e À inter-relação entre oralidade e escrita aqui abordadas procuraram, partindo da obra lobatiana, encontrar pistas para problematizar a mediação da leitura na escola. Vamos agora analisar o campo.

\section{NO CAMPO COM AS CRIANÇAS}

Destacaremos a seguir dois eventos que envolvem a mediação de Reinações de Narizinho (2007) junto a uma turma do $1^{\underline{0}}$ ano do Ensino Fundamental durante suas aulas de literatura, observadas ao longo de nove meses, em 12 diferentes encontros. Importante ressaltar que na escola observada a literatura é uma disciplina do currículo dos anos iniciais do ensino fundamental, as aulas acontecem semanalmente e têm duração de uma hora e 30 minutos. No projeto dessa escola, a obra de Lobato é contemplada do $1^{0}$ ao $5^{\circ}$ ano e livros do autor são lidos para, pelas e com as crianças, ao longo de todos esses 
anos. Como as crianças, nesse contexto de valorização da obra lobatiana, dialogam com ela? As mediações desenvolvidas pela professora contribuem para o envolvimento e produção de sentidos das crianças, no caso que observaremos, com o livro Reinações de Narizinho? Passemos assim à leitura e análises dos eventos destacados para este trabalho.

\section{Lê! Lêe! Lê!}

Professora anuncia que hoje contará a última parte do Reino das

Águas Claras, do livro Reinações de Narizinho.

Crianças: Êêêêêê!!! - (vibram). Reinações de Narizinho!!!

Diana: Se não tivesse tido feriado, a gente já estava no $2^{\circ}$ capítulo.

Fred: É. Parou na parte mais legal!

Professora: O que será então que vai acontecer? Vamos ler?

Crianças: Lê! Lê! Lê!

Professora começa a lembrar dos capítulos anteriores, recontando oralmente seus acontecimentos, e lembra-se da parte em que Narizinho chega ao Reino das Águas Claras. As crianças vão completando as lembranças:

Fred: O sapo estava dormindo!

Um menino se levanta e representa outra cena do sapo, dessa vez se olhando no espelho e, ao ver-se vestido com as roupas de Emília, levando um susto. Uma menina lembra-se da fala do Príncipe Escamado: "Seu pagamento agora vai ser engolir 100 pedrinhas, em vez de 100 moscas".

\section{$[\ldots]$}

Maria: Tia, eu me lembrei de uma coisa: nessa hora, a Emília tinha ganhado vida e pegou os óculos da carochinha e pisou em cima (levanta e faz o gesto interpretando a personagem).

Professora: Vamos ver se a gente acha essa parte...

Nisso, outra criança se lembra da parte do espelho da aranha costureira:

Natália: Aí, quebrou-se o encanto e o espelho quebrou.

Professora então reconta essa parte e uma menina diz:

Marta: E ela já era costureira há mil anos! (referindo-se à personagem Dona Aranha.)

Depois das lembranças, a professora passa a ler trechos do livro, ora adaptando algumas palavras, ora lendo e fazendo gestos que representam as expressões das personagens 
vendo a beleza do salão: as crianças repetem os gestos, arregalam os olhos, dizem oh!

À medida que vai lendo o texto no livro, a professora, por vezes, convida as crianças a representarem a história: diz as falas de cada personagem no ouvido das crianças e elas as repetem criando movimentos para interpretá-las. $O$ resto da turma fica bem atento, achando graça. No final desta parte, algumas crianças se dispersam, mas voltam a se interessar no momento em que a professora lê o desfecho da história, quando o Dr. Caramujo retira as "pedrinhas" da barriga do sapo.

Professora: Adivinha o que eram as pedrinhas?

Crianças: As pílulas falantes!

Professora ainda lê a parte em que Emília engole as pílulas e começa a falar tudo atrapalhado, sendo corrigida por Narizinho: "Só acordei quando o Doutor Cara de Coruja.../ Doutor Caramujo, Emília!/ Doutor Cara de Coruja! Só acordei quando o Doutor Cara de Corujíssima me pregou um liscabão!/Beliscão - emendou Narizinho.” As crianças estão só ouvindo a professora ler nesse momento e morrem de rir dessas falas, brincando em seguida de repeti-las (Caderno de Campo, 2012).

Iniciemos a análise trazendo as palavras de Abramovich (1989): "Ouvir histórias é viver um momento de gostosura, de divertimento dos melhores. É encantamento, sedução... O livro da criança que ainda não lê é a história contada" (ABRAMOVICH, 1989, p. 24). Esta é uma turma de $1^{0}$ ano, na qual as crianças ainda estão sistematizando os conhecimentos formais sobre a leitura e a escrita. Nas aulas de literatura, toda semana a professora narra uma história para elas. Nesse momento, desenvolve um projeto com o livro Reinações de Narizinho (2007), lendo-o (e, por vezes, recontando-o) em capítulos. Mas voltemos nosso olhar para a reação das crianças ao anúncio da professora: "Êêêêêê!! / Reinações de Narizinho!! / Se não tivesse tido feriado, a gente já estava no $2^{\circ}$ capítulo. / Parou na parte mais legal! / Lê! Lê! Lê!”. Para Abramovich, uma história pode ser "ampliadora de referenciais, torcida desenfreada, caminhos novos apontados, sorriso gargalhado" (1989, p. 24): as crianças, neste evento, estavam preparando-se para continuar a ouvir uma história e, nas reações demonstradas, intuímos que a experiência que vinham tendo com aquela leitura provocava-Ihes satisfação. Elas querem continuar ouvindo - "lê, lê, lệ" - e sabem que até já poderiam ter avançado na história, não fossem os feriados. Sabem também que estão diante de uma história longa, contada em capítulos, e intuem que as experiências já vividas com ela (gargalhas, torcidas, descobertas) continuarão acontecendo aos poucos. Contar histórias em capítulos é uma estratégia de mediação de leitura que estimula e aguça a curiosidade do leitor/ouvinte a respeito de seu desenrolar, como colocado anteriormente: por meio das lembranças sobre a história, é possivel observar as interpretações e compreensões que as crianças tiveram 
dos seus acontecimentos, o que aparece não só nas suas recordações, mas também em falas que tentam reproduzir os enunciados das personagens e do narrador: "Seu pagamento agora vai ser engolir 100 pedrinhas, em vez de 100 moscas / Aí, quebrou-se o encanto e o espelho quebrou / E ela já era costureira há mil anos!”

Também, nesse momento anterior ao novo mergulho na história, as crianças usam o corpo para reinterpretar ações das personagens: nesse movimento, repetem os percursos das personagens, revisitando e reelaborando a interpretação que deram a eles. Repetir os gestos das personagens, como reflete Benjamin (2002), corresponde à capacidade que o homem tem de produzir semelhanças. Na tentativa de lembrarem-se da história ouvida, as crianças se assemelham aos gestos e ações das personagens: “Tia, eu me lembrei de uma coisa: nessa hora, a Emília tinha ganhado vida e pegou os óculos da Dona Carochinha e pisou em cima” (a menina levanta e faz o gesto de tirar e pisar nos óculos, interpretando a personagem) - nesses momentos, não estão apenas imitando e repetindo, mas reelaborando a interpretação que deram ao texto e à ação de Emília, avançando contra a velha coroca que brigava com Narizinho. A mediação da professora também provoca nas crianças esse jogo de assemelhar-se às coisas para imprimir-lhes sentidos. Por vezes, faz gestos que as crianças mimetizam, depois passa a convidálas para entrar na história concretamente, por meio de dramatizações que acontecem simultaneamente à narração. De acordo com Oliveira (2010), dentre as estratégias que o professor pode lançar mão para deixar aflorar a sensibilidade dos leitores, está a da dramatização, uma vez que esta "propicia a exposição de um tema que os impactou, pelo inusitado de seu enredo ou pelo drama existencial que afeta qualquer ser humano" (OLIVEIRA, 2010 , p. 46). A proposta de mediação observada, no intuito de envolver as crianças, ajudando-as a dialogar com o texto, aliou narração e dramatização simultaneamente. As crianças, apesar de estarem entrando em contato com o inusitado do enredo daquele trecho da história, naquele momento já estavam de certa forma dentro dele, uma vez que vinham ouvindo Reinações de Narizinho há algumas aulas. A história já as havia impactado: elas já conheciam e identificavam-se com as personagens, tendo vivido imaginariamente seus dramas e impasses nas leituras anteriores. Por isso entraram facilmente na proposta da professora para viver, concretamente, novas situações daquelas personagens.

Ao nos debruçarmos sobre este evento, procuramos refletir sobre como leem as crianças antes de estarem alfabetizadas e como elas leram esta 
obra lobatiana. Na mediação da leitura, observamos diferentes formas de ler para as crianças - ler seguindo o texto, ler adaptando o texto ou recontando-o, ler promovendo interações corporais e teatrais. Também foi possível observar como as crianças interagiram com a leitura - mimetizando gestos das personagens, seguindo a narrativa apenas pela voz da professora, mobilizando-se com mais entusiasmo nas cenas que envolveram conflitos, impasses e revelações, ou então que eram engraçadas, como quando Emília começa a falar de forma atrapalhada.

A atração das crianças pela fala de Emília só pôde acontecer porque a professora lia o texto tal qual estava no livro, o que nos leva às reflexões tecidas sobre a inter-relação entre oralidade e escrita no trabalho com a literatura na escola. Se a professora estivesse recontando esse trecho do livro com suas palavras, não conseguiria o mesmo efeito de humor e irreverência que o texto apresenta e que são marcas tanto da escrita do autor quanto da personalidade de Emília. De acordo com Amarilha (1997), “ao ter contato com a literatura, a criança familiariza-se com estruturas linguísticas mais elaboradas porque é resultado do trabalho de um escritor - alguém que se especializou em propor desafios inteligentes, lúdicos através da língua” (AMARILHA, 1997, p. 56).

Lobato era um escritor que perseguia uma linguagem fluente, coloquial e inventiva. Desde Reinações de Narizinho, e muitas vezes por meio de Emília, o autor, segundo Sousa (2009), "usa e abusa da dimensão transgressora da linguagem, aproximando-se em muito da visão inaugural que a criança e o poeta têm do mundo" (SOUSA, 2009, p. 102). De acordo com a autora, o primeiro contato da criança com as palavras passa pelo prazer de repetir e saborear os sons, como as crianças nesse evento fizeram, no contato com o texto ouvido. Nesse jogo verbal e sonoro, perceptível nas invencionices e atrapalhações de Emília, ao começar a falar - liscabão, Polegada, Doutor Cara de Coruja -, aliado a sua personalidade atrevida, fez o encanto das crianças da turma, contribuindo para a interação e construção de sentidos para o texto.

Posso ser o Rabicó? e 0 porquinho é inocente

A professora retoma as partes do segundo capítulo de Reinações de Narizinho que ela vinha lendo nas aulas anteriores e as crianças vão se lembrando de acontecimentos e falas das personagens: Tia, como é mesmo aquele negócio da jabuticabeira? Pluft, ploct.../ Nhoque (completa a professora)/ Aonde estava a Narizinho? (professora pergunta)/ Ora! Na jabuticabeira! Ela vive lá! (criança responde). Depois a professora começa a nova leitura, alternando o reconto oral com a leitura do texto no livro, projetando também, na tela da TV, 
diferentes ilustrações das cenas e personagens que aparecem neste capítulo, acompanhadas de trechos do seu texto correspondente. Ora adaptando oralmente a narrativa, ora lendo-a, passando também do livro para a tela da TV com as ilustrações projetadas, vai conduzindo as novas partes deste capítulo. Dentre as imagens projetadas, encontram-se algumas que procuram ajudar na compreensão de elementos do texto, desconhecidos das crianças, como uma jabuticabeira e o personagem Tom Mix.

Na parte mais emocionante do capítulo, quando o bandido Tom Mix surge para assaltar Narizinho, Emília e Rabicó, e o porquinho foge, as crianças prestam a maior atenção. Narizinho fica danada com a fuga de Rabicó, mas consegue livrar-se com esperteza do bandido, oferecendo-lhe em lugar do ouro que ele queria um pouco da macela (dourada) da perna de Emília. $O$ bandido fica satisfeito e diz que dali para a frente poderá ajudá-la sempre que quiser, bastando chamá-lo: Mix! Mix! Mix! As crianças adoram essa parte e ficam repetindo as falas do bandido: A bolsa ou a vida! Ou: Mix! Mix! Mix!

Marcos: Tia, posso ser o bandido? Tiago: Posso ser o Rabicó?

A professora propõe a teatralização e depois lê o final da narrativa, quando Narizinho chama Tom Mix para dar uma lição em Rabicó, por este ter fugido na hora do perigo, dizendo ao bandido o que desejava para o almoço do dia seguinte: feijão com torresmo de Marquês (o Rabicó). Neste diálogo do livro, Emília entende qual será a vingança de Narizinho, fica com pena de Rabicó e então a cena termina (Caderno de Campo, 2012).

Nesta parte do evento, as crianças estão envolvidas na sequência dos capítulos de Reinações de Narizinho (2007), lembrando-se de seus acontecimentos, mostrando estar compreendendo a narrativa e voltando à experiência com a linguagem lúdica do escritor (e lida pela professora): “Mix! Mix! Mix! A bolsa ou a vida! Pluct, ploft, nhoque!” Também é possível perceber a mediação da professora, ora recontando, ora lendo e, desta vez, incluindo, na tela da TV, ilustrações de cenas da história ou de personagens e elementos desconhecidos das crianças, para também fazerem parte de sua leitura/contação, procurando contribuir para a interação das crianças com a obra. Segundo a professora, em entrevista concedida à pesquisa, as crianças de hoje têm dificuldades de manter a atenção por muito tempo. Por isso, para mantê-las atentas numa história mais longa, além da leitura em capítulos, também procura quebrar sua sequência, "intercalando-a com perguntas, provocando uma sensação: o que será que vai acontecer?” (Entrevista/professora, 2012). Refletindo sobre a experiência de turmas do $1^{0}$ ano com a obra lobatiana, ressalta o gosto das crianças desta idade pela magia presente nos textos do escritor e aponta como elas vão entrando nesse mundo: 
Elas começam questionando o que acontece com uma lógica muito racional. Depois,

quebram isso e mergulham. E quando começam a dramatizar, na aula seguinte ficam falando: "mas eu fui a Narizinho, então agora eu sou Narizinho". [...] Mesmo sabendo que não são as personagens, gostam desse jogo, e isso faz bem (Entrevista/professora, 2012).

Por outro lado, a professora aponta para as dificuldades de compreensão das crianças sobre coisas que não conhecem: "a gente foi sentindo necessidade de trazer os elementos que eles não conhecem para facilitar essa compreensão. Mediar esta compreensão. O que é um sabugo de milho? Quem é o Tom Mix? Coisas que não fazem parte da vivência atual deles" (Entrevista/professora, 2012).

Aescola onde foi desenvolvida esta pesquisa tem a preocupação de que a leitura de Lobato aconteça de forma significativa e as observações evidenciaram que a mediação planejada foi importante para a construção de sentidos por parte das crianças. Recursos como fotografias, episódios da série televisiva, ilustrações de livros, formas diversas de ler - ler integralmente o texto, ler adaptando, ler dramatizando - contribuíram para isso. A leitura oralizada de um texto vem sendo discutida por diferentes autores, como já destacado, e a própria professora, numa conversa informal durante a pesquisa, comentou que se sentia “autorizada pelo Lobato" para fazer determinadas adaptações na linguagem e na forma de ler, citando o mesmo trecho da obra, já destacado neste trabalho: “Leia de sua moda, vovó! [...], a boa velha lia traduzindo aquele português de defunto [...]. Onde estava 'lume', lia 'fogo' [...], e ficava o dobro interessante" (LOBATO, 2007, p. 36).

Voltando à análise, a professora tem como objetivo ler Reinações de Narizinho (2007) para uma turma do $1^{0}$ ano, pois observa que o livro apresenta possibilidades de interlocução junto a crianças de 6/7 anos. Ao perceber as dificuldades que ele também oferece, procura estratégias para resolvêlas. Além disso, para favorecer a permanência das crianças no texto, busca provocá-las nos momentos de impasse, não só para aguçar a curiosidade, mas para abrir espaços de diálogo.

Passemos à segunda parte da análise, observando a conversa entre as crianças e a professora, quando o capítulo termina, com Narizinho pedindo a Tom Mix para capturar Rabicó, pois ela quer almoçá-lo no dia seguinte. Nesse diálogo, Emília fica com pena de Rabicó: “Coitado do Rabicó - exclamou Emília compungida”. Ao que Narizinho responde: “Coitado nada! Rabicó precisa levar uma boa esfrega" (LOBATO, 2007, p. 58). 
Professora: E agora, o que vai acontecer?

Ludmila: Eu não sei.

Marcos: Eu acho que ela vai salvar o Rabicó!

Natália: Não vai não.

Fred: O porquinho é inocente.

Gláucia: Eu não acho que ela vai salvar porque ele comeu os bolinhos.

Professora: Você acha que ela não vai perdoar?!

Gláucia: Acho.

Fred: Eu acho que vai!

Professora: Vamos fazer uma votação? A Narizinho vai salvar ou não o Rabicó? (A maioria das crianças votou pelo salvamento, menos duas meninas.)

Professora: Natália, por que você acha que a Narizinho não vai salvar o Rabicó?

Natália: Porque ele comeu os bolinhos e os croquetes da Narizinho. (Caderno de Campo, 2012).

Esta parte do evento possibilita observar diferentes reações e reflexões dos leitores sobre o universo da história ouvida: Rabicó deve ser perdoado pelo que fez? 0 que passa na cabeça de cada leitor? Se o texto estivesse sendo lido silenciosamente por um único leitor, só ele conheceria seus posicionamentos, mas ele estava sendo compartilhado numa turma e, na provocação da professora, abre-se espaço para que o diálogo agora seja entre os diferentes leitores e suas diferentes leituras. Como comentam Silva e Martins (2010), as leituras serão sempre diferentes de um leitor para o outro, pois cada um só pode estabelecer relações com o mundo que conhece. As opiniões e escolhas das crianças diferem porque suas histórias de vida, seus valores e horizonte social também são diversos e é a partir deles que elas dialogam com o texto. Neste evento, os leitores, como numa "arena" (BAKHTIN, 1988), se colocaram de formas diferentes, contrapondo opiniões e explicando os motivos dos posicionamentos. Cada enunciação provocou a que veio a seguir e cada um dos leitores foi construindo, nas diferentes vozes ouvidas, sua compreensão sobre o texto. 


\section{CONSIDERAÇÕES FINAIS}

Neste trabalho, tivemos como objetivo observar e analisar as mediações de leitura por dentro da obra de Monteiro Lobato para, a partir delas, problematizar as mediações de leitura que ocorrem ou podem ocorrer nas salas de aula, trazendo questões sobre a inter-relação entre a oralidade e a escrita, no trabalho com a leitura literária nas escolas. Em que situações de leitura, com crianças ainda pequenas, pode se tornar importante fazer adaptações num texto para favorecer o diálogo com ele? Em contrapartida, o que se perde de experiência com a linguagem literária quando não se lê o livro tal qual foi elaborado pelo autor, no ritmo criado pela escrita, nas sonoridades das palavras, nos efeitos que elas podem provocar? Essas discussões estão na obra de Lobato e podem ajudar a pensar o trabalho que envolve a mediação da leitura na escola.

O trabalho evidenciou, nas análises realizadas sobre o universo da obra, como as mediações de leitura utilizadas por Dona Benta contribuíram em diferentes aspectos para o envolvimento de seus ouvintes com os textos, ajudando-os a construir sentidos e a ampliar suas experiências culturais. Estratégias tais como ler e provocar um diálogo após a leitura, ler oralmente, buscando recursos de entonação e da voz, ler em capítulos, adaptar a linguagem à experiência do leitor iniciante, quando necessário, dialogar com os ouvintes ao longo das narrações sobre as situações das histórias e sobre a arte literária, buscar verossimilhança entre os personagens das histórias e os ouvintes mostraramse provocativas para as crianças do Sítio, levando-as a identificarem-se com as personagens dos livros que ouviam, elaborando sentidos para suas histórias e dialogando com o mundo no qual estão inseridas.

Nos dois eventos destacados no âmbito da escola, a leitura mediada também foi determinante para as interações e diálogos das crianças com Reinações de Narizinho. As estratégias para compartilhar histórias, desenvolvidas pela professora da turma - ler em voz alta; ler em capítulos; ler partes do texto e adaptar outras; ler fazendo gestos; ler mostrando as ilustrações; ler, perguntar e anunciar; ler dramatizando; ler compartilhando e ampliando as referências dos leitores sobre o texto - práticas que se aproximam das de Dona Benta - contribuíram para que as crianças fossem afetadas por aquela leitura, adentrando seu universo imaginário e reelaborando o real. As estratégias de mediação, aliadas ao planejamento intencionalmente pensado para aquela leitura (um clássico) - a professora trazia recursos que pretendiam minimizar possíveis dificuldades, organizava sua maneira de ler (adaptando, lendo 
integralmente, dramatizando o texto) - foram capazes de provocar o diálogo das crianças com Reinações de Narizinho (2007), inclusive porque mostraram reconhecer a capacidade das crianças pequenas de pensar e negociar sentidos sobre o que leem, respeitando também os seus modos de ler. 


\section{From Dona Benta's Living Room to the Classroom: Contributions to Think about Literary Reading Mediation in School}

Abstract: The present article discusses how reading mediations, which are perceptible in Monteiro Lobato's works, can become leads to think about approaches to literature in school. We analyzed mediation strategies in narratives by Lobato, as well as the mediated reading of one of them, with children in the first grade of primary education in a Brazilian public school. With regard to methodology, we conducted readings of works by Lobato and studies about them, participant observations, and interviews with the teacher of the class. Bakhtin (2011) and Benjamin (1995) founded our conceptions of language and subject, and underpin theoretical-methodological questions in this study. In the field of literary reading, we sought a dialogue with Amarilha (1997), Abramovich (1989), Bajard (2007) and Lajolo (1994). After the analyses, we highlighted a set of mediation practices that seem to contribute to promote children's contact with literature.

Keywords: Literary reading. School. Mediations. Monteiro Lobato. 


\section{De la sala de doña Benta al aula: contribuciones para plantear la mediación de la lectura literaria en la escuela}

Resumen: Este trabajo discute cómo las mediaciones de la lectura, perceptibles en la obra de Monteiro Lobato, pueden volverse pistas para plantear el trabajo con la literatura en la escuela. Se analizaron estrategias de mediación en narraciones lobatianas, así como la lectura mediada de una de ellas, con niños del 1.er año de la enseñanza básica en una escuela pública brasileña. La metodología incluyó lecturas de obras de Lobato y de estudios sobre ellas, observaciones de los participantes y una entrevista con la profesora de la clase. Bajtín (2011) y Benjamin (1995) establecen bases para los conceptos de lenguaje y de sujeto y sostienen cuestiones teórico-metodológicas de esta investigación. En el campo de la lectura literaria, se buscó el diálogo con Amarilha (1997), Abramovich (1989), Bajard (2007) y Lajolo (1994). Después de los análisis, se destacó un conjunto de prácticas de mediación que parecen contribuir al encuentro de los niños con la literatura.

Palabras clave: Lectura literaria. Escuela. Mediaciones. Monteiro Lobato. 


\section{REFERÊNCIAS}

ABRAMOVICH, Fanny. Literatura infantil: gostosuras e bobices. São Paulo: Scipione, 1989.

AMARILHA, Marly. Estão mortas as fadas? Literatura infantil e prática pedagógica. Petrópolis: Vozes, 1997.

BAJARD, Elie. Da escuta de textos à leitura. São Paulo: Cortez, 2007.

BAKHTIN, Mikhail. Marxismo efilosofia da linguagem: problemas fundamentais do método sociológico da linguagem. São Paulo: Hucitec, 1988.

BENJAMIN, Walter. Reflexões sobre a criança, o brinquedo e a educação. São Paulo: Ed. 34, 2002.

LAJOLO, Marisa. Do mundo da leitura para a leitura do mundo. São Paulo: Ática, 1994.

LOBATO, Monteiro. Reinações de Narizinho. São Paulo: Globo, 2007.

. Fábulas. São Paulo: Globo, 2008.

Peter Pan. São Paulo: Globo, 2009.

. Dom Quixote das crianças. São Paulo: Globo, 2010.

OLIVEIRA, Ana Arlinda de. O professor como mediador das leituras literárias. In: PAIVA, Aparecida (Org.). Literatura: ensino fundamental. Brasília: Ministério da Educação, Secretaria de Educação Básica, 2010. (Coleção Explorando o Ensino).

PIMENTEL, Claudia. Tesouro Monteiro Lobato. Guia do Professor. São Paulo: Globo, 2010.

SILVA, Márcia Cabral da; MARTINS, Milena Ribeiro. Experiências de leitura no contexto escolar. In: PAIVA, Aparecida (Org.). Literatura: ensino fundamental. Brasília: Secretaria de Educação Básica, 2010. (Coleção Explorando o Ensino).

SOUSA, Margarida Maria Alacoque Chaves. Emília: potencialidade transgressora na formação de um novo conceito de infância. 2009. Dissertação. Faculdade de Letras/ Estudos Literários - UFMG. Belo Horizonte, 2009.

SOUZA, Loide Nascimento. Monteiro Lobato e o processo de reescritura das 
fábulas. In: LAJOLO, Marisa (Org.). Monteiro Lobato livro a livro: obra infantil. São Paulo: Unesp, 2008.

ZILBERMAN, Regina; MAGALHÃES, Ligia Cademartori. Literatura infantil: autoritarismo e emancipação. São Paulo: Ática, 1987.

Sobre a autora:

Sônia Travassos é Mestre e doutoranda em Educação pela Universidade Federal do Rio de Janeiro (UFRJ).

soniamariatravassos@gmail.com

Recebido em: abril de 2016

Aprovado em: junho de 2016 